\title{
Undetectable serum IgA and low IgM concentration in children with congenital hypothyroidism
}

\author{
Stefano Stagi ${ }^{\mathrm{a}}$, Chiara Azzari ${ }^{\mathrm{b}, *}$, Giuseppe Bindi ${ }^{\mathrm{a}}$, Fiorella Galluzzi ${ }^{\mathrm{a}}$, Sergio Nanni ${ }^{\mathrm{b}}$, \\ Roberto Salti ${ }^{\mathrm{a}}$, Alberto Vierucci ${ }^{\mathrm{b}}$ \\ ${ }^{a}$ Pediatric Endocrinology Unit, A. Meyer Children Hospital, Florence, Italy \\ ${ }^{\mathrm{b}}$ Pediatric Immunology and Allergy Unit, Department of Pediatrics, University of Florence, Anna Meyer Children Hospital, \\ Via Luca Giordano 13, Florence, Italy
}

Received 7 January 2005; accepted with revision 4 March 2005

Available online 16 April 2005

\begin{abstract}
Some studies suggest thyroid hormones may regulate the human immune system. In order to evaluate the effect of thyroid hormone deficiency on antibody production, we evaluated serum $\operatorname{IgA}$ and $\operatorname{IgM}$ concentrations in 83 children with congenital hypothyroidism $(\mathrm{CH})$, diagnosed by neonatal screening. Patients were compared to two healthy, age-matched control groups. Patients with permanent $\mathrm{CH}$ had a significantly higher frequency of undetectable $\operatorname{IgA}$ concentrations (thyroid agenesis, $P<10^{-5}$; thyroid ectopy, $P=0.013$ ) and lower concentrations of IgA (thyroid agenesis, $P<10^{-6}$; thyroid ectopy, $P<10^{-5}$; dyshormonogenesis, $P=0.0002$ ) and IgM (thyroid agenesis, $P=$ 0.0002 ; thyroid ectopy, $P<10^{-6}$; dyshormonogenesis, $P=0.0017$ ) compared to control group. No difference was observed between patients with transient hypothyroidism and controls. A significant correlation was observed between serum $\operatorname{IgA}$ and IgM concentrations and $\mathrm{fT}_{4}$ levels. IgA and IgM deficiency is correlated with the severity of congenital hypothyroidism and may help to evaluate the duration and severity of thyroid hormone deficiency during prenatal life.
\end{abstract}

(C) 2005 Published by Elsevier Inc.

Keywords: Congenital hypothyroidism; Immunoglobulin; IgA; IgM; Immune system; Thyroid hormones

\section{Introduction}

Thyroid hormones are known to influence many human cells and control the development and function of many organs.

Interactions between thyroid hormones and the immune system development and function have been demonstrated in experimental studies on animals. The first studies, carried out more than 70 years ago, showed that adenohypophysis ablation caused thymic atrophy in mice [1]. Similarly, a report on humans showed that thymic development was significantly reduced and thymic tissue was atrophic in patients with sporadic congenital hypothyroidism [2]. In more recent years, several studies have clarified the role of

\footnotetext{
* Corresponding author. Fax: +39055 570380 .

E-mail address: c.azzari@meyer.it (C. Azzari).
}

thyroid hormones on primary and secondary lymphopoiesis [3-8].

B cell development is defective in genetically hypothyroid mice, such as dw/dw [3,9], hyt/hyt [3], and TR $\alpha-/-$ inbred mice [5]. Similarly, B cell lymphopoiesis, but not T cell production, is affected by thyroid hormone deficiency in hyt/hyt mice [3]. Secondary lymphocyte development, however, is normal in both dw/dw and hyt/hyt mice, and a normal humoral response to T-dependent and T-independent antigens has been demonstrated in those animals $[3,10]$.

Although case reports have been published on the immune function in hypothyroid patients [11-14], the interaction between thyroid hormones and the immune system development and function in humans has not been completely clarified. The aim of the present study was to evaluate the role of hypothyroidism on immunoglobulin levels in children with congenital hypothyroidism at the time of diagnosis. 


\section{Patients and methods}

\section{Patients}

Eighty-three patients (35 males, 48 females, born fullterm), diagnosed with congenital hypothyroidism, were included in the study. The patients were divided into four groups, according to their diagnosis. Sixteen patients had transient hypothyroidism, 17 had dyshormonogenesis, 30 had thyroid ectopy, and 20 had thyroid agenesis. Thyroid agenesis was diagnosed when a $99 \mathrm{mTc}$-pertechnetate thyroid scan, performed at the time of diagnosis, showed no radionuclide uptake. Thyroid ectopy was diagnosed when a $99 \mathrm{mTc}$-pertechnetate thyroid scan showed either a smaller volume of thyroid or its abnormal position. Dyshormonogenesis was diagnosed when a normal or increased uptake of $99 \mathrm{mTc}$ was revealed in a position that is normal for the thyroid gland [15]. Transient neonatal hypothyroidism was diagnosed in the presence of increased concentrations of thyroid stimulating hormone (TSH) with normal or decreased $\mathrm{fT}_{4}$, both returning to normal levels within 1 month after birth and associated with normal thyroid morphology and normal $99 \mathrm{mTc}$ uptake [16].

The biochemical severity of congenital hypothyroidism was assessed from the first quantitative thyroxine $\left(\mathrm{fT}_{4}\right)$ and thyroid-stimulating hormone (TSH) measurements, before initiation of thyroid replacement therapy. Since thyroid ectopy and thyroid agenesis are usually diagnosed at an earlier age than transient hypothyroidism and dyshormonogenesis because of the severity of the symptoms, two different control groups, matched for sex and age, were enrolled in the study. Control group 1 included 102 healthy controls, sex- and age-matched with the transient hypothyroidism and dyshormonogenesis group. Control group 2 included 49 healthy controls, sex- and age-matched with the thyroid ectopy and thyroid agenesis group. All the control children underwent a review of their medical history, a physical examination and a nutritional assessment, as well as biochemical and endocrine examinations. The main features of the patient and control groups (sex and age at diagnosis, and type of feeding) and the diagnosis are reported in Table 1.

The ethics committee of Meyer Children's Hospital approved the study; informed written consent was obtained from the parents of all subjects.

\section{Laboratory methods}

Free- $\mathrm{T}_{4}$ and $\mathrm{TSH}$ serum levels were determined by immunometric assays (Immulite ${ }^{\mathrm{TM}} 2000$ Third generation, DPC Diagnostic Products Corporation, Los Angeles, CA, USA). Within- and between-run coefficients of variation were less than $12.5 \%$ for TSH, and were less than $7.5 \%$ for $\mathrm{fT}_{4}$. The normal range of $\mathrm{fT}_{4}$ and $\mathrm{TSH}$ serum concentrations were $0.8-1.9 \mathrm{ng} / \mathrm{dl}$ and $0.4-4 \mu \mathrm{UI} / \mathrm{ml}$.
Table 1

Main features of patients and controls included in the study

\begin{tabular}{|c|c|c|c|c|}
\hline & $\begin{array}{l}\text { Patients } \\
\text { (n) }\end{array}$ & $\begin{array}{l}\text { Sex } \\
(\mathrm{M} \text { or F) }\end{array}$ & $\begin{array}{l}\text { Age at } \\
\text { diagnosis, } \\
\text { mean } \pm \mathrm{SD} \\
\text { (days) }\end{array}$ & $\begin{array}{l}\text { Type of feeding } \\
\text { (breast- or } \\
\text { bottle-feeding) }\end{array}$ \\
\hline $\begin{array}{l}\text { Transient } \\
\text { hypothyroidism }\end{array}$ & 16 & $10 \mathrm{M}, 6 \mathrm{~F}$ & $33.2 \pm 10.5$ & $\begin{array}{l}13 \text { breast, } \\
3 \text { bottle }\end{array}$ \\
\hline Dyshormonogenesis & 17 & $10 \mathrm{M}, 7 \mathrm{~F}$ & $33.7 \pm 18.6$ & $\begin{array}{l}14 \text { breast, } \\
3 \text { bottle }\end{array}$ \\
\hline Thyroid ectopy & 30 & $11 \mathrm{M}, 19 \mathrm{~F}$ & $22.6 \pm 6.4$ & $\begin{array}{l}27 \text { breast, } \\
3 \text { bottle }\end{array}$ \\
\hline Thyroid agenesis & 20 & $4 \mathrm{M}, 16 \mathrm{~F}$ & $25.0 \pm 7.2$ & $\begin{array}{l}15 \text { breast, } \\
5 \text { bottle }\end{array}$ \\
\hline Total & 83 & $35 \mathrm{M}, 48 \mathrm{~F}$ & $27.5 \pm 11.8$ & $\begin{array}{l}69 \text { breast, } \\
14 \text { bottle }\end{array}$ \\
\hline Control group 1 & 102 & $56 \mathrm{M}, 46 \mathrm{~F}$ & $36.8 \pm 15.5$ & $\begin{array}{l}80 \text { breast, } \\
22 \text { bottle }\end{array}$ \\
\hline Control group 2 & 49 & $21 \mathrm{M}, 28 \mathrm{~F}$ & $22.7 \pm 7.1$ & $\begin{array}{l}37 \text { breast, } \\
12 \text { bottle }\end{array}$ \\
\hline
\end{tabular}

Immunoglobulin concentrations were measured by ELISA (IgA-human-ELISA quantitation kit and IgMhuman-ELISA quantitation kit, Vinci Biochem, Vinci, Italy). Values lower than $10 \mathrm{mg} / \mathrm{dl}$ for $\operatorname{IgA}$ and lower than $20 \mathrm{mg} / \mathrm{dl}$ for IgM were retested by radial immunodiffusion technique (The Binding Site, Birmingham UK; lower limit of detection: $0.8 \mathrm{mg} / \mathrm{dl}$ for $\mathrm{IgA}$ and $0.7 \mathrm{mg} / \mathrm{dl}$ for $\operatorname{IgM}$ ), using serum dilution when appropriate. $\operatorname{Ig} \mathrm{A}$ concentrations were considered undetectable when they were $<0.8 \mathrm{mg} / \mathrm{dl}$ in two separate assays. The intra- and inter-assay coefficients of variation for $\operatorname{IgA}$ and $\operatorname{IgM}$ concentrations were less than 2.1 and $2.7 \%$, respectively. CD19+ B cells, as well as B cells bearing surface membrane $\operatorname{IgM} / \operatorname{IgD}[\operatorname{SmIg}(\mathrm{D}+\mathrm{M}+)]$, were enumerated by flow cytometry using fluorescein or phycoerythrin-conjugated monoclonal antibodies (Becton Dickinson, San José, CA, USA). Flow cytometry was performed on a Becton-Dickinson FACScan (Becton-Dickinson, San Jose, CA, USA) immediately after cell staining.

Differences between means (analyzed by the Student's $t$ test for unpaired samples), differences in frequencies (evaluated by $\chi^{2}$ test or Fisher's exact probabilities, as appropriate), and correlation analyses (Pearson) were measured using an SPSSX statistical package (SPSS Inc., Chicago, IL). For analysis of correlation, TSH values over $100 \mu \mathrm{UI} / \mathrm{ml}$ were considered as 100 . For the same purposes, $\mathrm{fT}_{4}$ values less than $0.1 \mathrm{ng} / \mathrm{dl}$ were considered as 0.1 and IgA values less than $0.8 \mathrm{mg} / \mathrm{dl}$ were considered as 0.8 . Twotailed $P$ values were determined and $P$ values $<0.05$ were considered significant.

\section{Results}

No abnormalities were found in the medical history, the physical examination, the nutritional assessment, and the biochemical or endocrine examination within the control groups. 
No differences were found in the sex distribution and mean age between any group of patients and their control group. Similarly, no differences in type of feeding were found between any of the four groups of patients and their control group. Within the control groups, no difference was found in serum $\operatorname{IgA}$ and $\operatorname{IgM}$ concentration between males and females.

The frequency of undetectable serum IgA was significantly higher in patients with thyroid agenesis $(12 / 20$, $60 \%)$ and thyroid ectopy $(7 / 30,23.3 \%)$, compared to their control group $(2 / 49,4.1 \%)$, while no difference was found between serum $\operatorname{IgA}$ concentrations of patients with dyshormonogenesis $(2 / 17,11.8 \%)$ or transient hypothyroidism $(0 / 16)$ and their controls $(3 / 102,2.9 \%)$. Data are shown in Table 2. Compared to control group 1, the frequency of undetectable serum IgA was higher, and the serum $\operatorname{IgA}$ concentrations were lower, as expected, in control group 2 (younger controls), but this difference did not reach statistical significance. Serum IgA concentrations were significantly lower in patients with thyroid agenesis or thyroid ectopy or dyshormonogenesis compared to their control groups. No difference was found between serum IgA concentrations in patients with transient hypothyroidism and their control. Data are shown in Table 2. IgM concentrations were significantly lower in patients with thyroid agenesis, thyroid ectopy, and dyshormonogenesis, compared to their control groups, while no difference was found between $\operatorname{IgM}$ concentrations of patients with transient hypothyroidism and their control group (Table 2). In evaluating all groups of patients, a correlation was found between $\mathrm{fT}_{4}$ levels and serum IgA concentrations $\left(r=0.74 ; P<10^{-5}\right)$ and between $\mathrm{fT}_{4}$ and serum $\mathrm{IgM}$ concentrations $\left(r=0.52 ; P<10^{-5}\right)$. A negative correlation was found between $\operatorname{IgA}$ concentrations and TSH $(r=$ $-0.56, P<10^{-5}$ ) and between IgM concentrations and TSH $\left(r=-0.46 P<10^{-5}\right)$. The percentage of CD19+ and $\mathrm{SmIg}(\mathrm{D}+\mathrm{M}+)$ B cells was 17.9 (range 9-29) and 16.3 (range 8-24), respectively, in the 83 patients included in the study [normal value $6-25 \%$ for both CD19+ and $\mathrm{SmIg}(\mathrm{D}+\mathrm{M}+)$ cells $]$.

\section{Discussion}

Increasing evidence shows that the immune system operates in a coordinated way with the neuroendocrine system and that immune cells can be influenced by hormones, neurotransmitters, and neuropeptides $[17,18]$.

The present study shows that children with permanent congenital hypothyroidism (thyroid agenesis, thyroid ectopy, dyshormonogenesis) have a defect in immunoglobulin production. The frequency of undetectable serum $\operatorname{IgA}$ concentrations is significantly higher in patients with these disorders than in controls and the defect is more common in patients with the most severe hypothyroidism. Similarly, serum IgM concentrations are significantly lower in patients with hypothyroidism and there is a strong correlation between the concentrations of $\operatorname{IgA}$ or $\operatorname{IgM}$ and the concentrations of $\mathrm{fT}_{4}$. The $\mathrm{IgG}$ level was not considered as a reliable parameter for evaluation of antibody production in the neonate because neonatal serum $\operatorname{IgG}$ concentrations reflect the transplacental passage of $\mathrm{IgG}$ from the mother in the third trimester, rather than the neonatal antibody synthesis. In contrast to infants with persistent hypothyroidism, the frequency of undetectable serum $\operatorname{IgA}$ concentrations in patients with neonatal transitory hypothyroidism is identical to that found in healthy controls. Furthermore, IgM concentrations are also normal in transitory hypothyroidism patients. These data suggest that transitory hypothyroidism has no effect on B cell development and/or function. These findings differ from data obtained in animal studies that demonstrate that transitory propylthiouracil-induced hypothyroidism in the earliest phases of development causes transient changes in thymic $\mathrm{T}$ cell development in immune cell sub-populations and delayed B cell development. However, immunoglobulin concentrations were not reported in those studies [19].

It is not easy to speculate whether the effect of $\mathrm{fT}_{4}$ deficiency acts directly on $\mathrm{B}$ cell function or if it is dependent on other factors. In humans, thyroid hormones exert immunomodulatory activities and the thymus is one of their target organs [20]. Thyroid hormone receptors are

Table 2

$\operatorname{IgA}$ and $\operatorname{IgM}$ serum concentrations in hypothyroidism patients and control groups

\begin{tabular}{|c|c|c|c|c|c|c|}
\hline Diagnosis & $\begin{array}{l}\text { IgM levels }(\mathrm{mg} / \mathrm{dl}) \\
\text { mean } \pm \mathrm{SD}\end{array}$ & $P$ & $\begin{array}{l}\text { Frequency of } \\
\text { undetectable } \\
\operatorname{IgA}^{\mathrm{a}}, n(\%)\end{array}$ & $P$ & $\begin{array}{l}\text { IgA levels }(\mathrm{mg} / \mathrm{dl}) \\
\text { mean } \pm \mathrm{SD}\end{array}$ & $P$ \\
\hline $\begin{array}{l}\text { Transient } \\
\text { hypothyroidism }\end{array}$ & $40.4 \pm 15.7$ & ns & $0 / 16(0)$ & 0.64 & $7.2 \pm 7.4$ & ns \\
\hline Dyshormonogenesis & $28.6 \pm 9.9$ & 0.0017 & 2/17 (11.8) & 0.14 & $4.5 \pm 2.6$ & 0.0002 \\
\hline Control group 1 & $41.6 \pm 15.4$ & - & $3 / 102(2.9)$ & - & $11.1 \pm 7.0$ & - \\
\hline Thyroid ectopy & $23.2 \pm 5.9$ & $<10^{-6}$ & $7 / 30(23.3)$ & 0.013 & $2.6 \pm 2.4$ & $<10^{-5}$ \\
\hline Thyroid agenesis & $22.1 \pm 6.9$ & 0.0002 & $12 / 20(60.0)$ & $<10^{-5}$ & $0.9 \pm 0.2$ & $<10^{-6}$ \\
\hline Control group 2 & $38.8 \pm 15.2$ & - & $2 / 49(4.1)$ & - & $9.2 \pm 6.9$ & - \\
\hline
\end{tabular}

$\mathrm{ns}=$ Not significant.

$\mathrm{SD}=$ standard deviation .

${ }^{a}$ Undetectable $\operatorname{IgA}$ was defined as $\operatorname{IgA}<0.8 \mathrm{mg} / \mathrm{dl}$. 
present on lymphocytes and studies in mice have demonstrated that thyroid hormones have a direct role in B cell development and that they are required for normal B cell production in the bone marrow $[3,4]$. In the present study, no decrease in the percentage of $\mathrm{CD} 19+$ or $\mathrm{SmIg}(\mathrm{D}+\mathrm{M}+) \mathrm{B}$ cells was demonstrated in any of the groups of patients studied. The defect of immunoglobulin production, therefore, does not seem to be due to a reduction of antibodyproducing cells but to a functional defect.

On the other hand, it cannot be excluded that immunoglobulin production defect in hypothyroidism patients is related to the high levels of TSH present in these patients. Thyroid-stimulating hormone has a variety of immuneregulating cytokine-like activities that can influence $\mathrm{T}$ cell development in the thymus and intestine, and affect humoral and cell-mediated responses of peripheral lymphocytes [21]. Many hematopoietic cells in the bone marrow produce TSH and express the TSH receptor, as do subsets of dendritic cells, monocytes, and lymphocytes in the spleen and lymph nodes [21].

Another mechanism could be hypothesized: the action of the TSH and thyroid hormone could be mediated by other hormones or neurotransmitters. For example, thyroid hormones have a permissive action on the adrenergic function and patients with untreated hypothyroidism have a down-regulation of the adrenergic receptor [22-24]. Adrenergic stimulation increases antibody production by B cells [18]. Therefore, the effect of hypothyroidism on IgA and IgM synthesis might be mediated by adrenergic downregulation. Experiments performed on animals demonstrate that both beta-adrenergic receptor expression and $\operatorname{IgM}$ production are increased in hyperthyroid mice and decreased in hypothyroid mice after immunization and that IgM production is related to regulation of beta-adrenergic receptors on immune cells [25]. The low levels of IgA and IgM found in patients with congenital hypothyroidism did not result in an increased number or severity of infections. It may be hypothesized that the normal values of serum IgG concentrations, due to the transplacental passage of that isotype of immunoglobulin, are a sufficient help against infections in these patients during the first months of life. The follow-up of patients included in the present study, ongoing in our clinic, will clarify whether low serum IgM or IgA concentrations are associated with a suboptimal response to immunization.

Patients with untreated congenital hypothyroidism usually have severe neurological and growth impairment [26], and even patients who are treated promptly may have neurological damage and mild motor and neuropsychological impairment [26].

Many parameters ( $\mathrm{fT}_{4}$ level at birth, TSH level at birth, age at diagnosis, age of treatment start, initial thyroid replacement therapy dosage, bone age at birth, electroencephalogram at birth) have been reported to be prognostic factors for growth or neuropsychological development [2731]. Some of these features have also been used as indicators of the severity of prenatal thyroid hormone deficiency. However, none of these parameters accurately reflect the severity or age at onset of hormone deficiency during fetal life.

The present study shows that patients with permanent congenital hypothyroidism have lower concentrations of IgM than controls and an extremely high frequency of undetectable serum IgA concentrations. IgM serum concentrations are directly related to the severity of hormone deficiency and the lowest values of $\operatorname{IgM}$ can be found in those patients (thyroid agenesis, thyroid ectopy) in which the defects have their onset earlier during prenatal life. Therefore, the presence of normal levels of IgM or IgA in an infant with hypothyroidism could be considered as a positive prognostic factor, suggesting a less severe deficiency of thyroid hormones or a later age of onset during fetal life. Long-term follow-up of patients included in the present study will clarify whether serum $\operatorname{IgM}$ or $\operatorname{IgA}$ concentrations also predict the prognosis for neurological development or growth of congenital hypothyroidism patients. Preliminary data suggest that serum $\operatorname{IgA}$ and $\operatorname{IgM}$ concentrations gradually increase after L-thyroxine therapy has started. Further studies are also necessary to clarify the mechanisms underlying the thyroid control of antibody production in congenital hypothyroidism.

\section{Acknowledgment}

We sincerely thank Andrea Zampino for expert technical assistance.

\section{References}

[1] P. Smith, The effect of hypophysectomy upon the involution of the thymus in the rat, Anat. Rec. 47 (1930) 119-143.

[2] J. Erdheim, Über Schilddrüsenaplasie, Beitr. Pathol. Anat. 35 (1904) 366.

[3] E. Montecino-Rodriguez, R.G. Clark, L. Powell-Braxton, K. Dorshkind, Primary B cell development is impaired in mice with defects of the pituitary/thyroid axis, J. Immunol. 159 (1997) 2712-2719.

[4] M.P. Foster, E. Montecino-Rodriguez, K. Dorshkind, Proliferation of bone marrow pro-B cells is dependent on stimulation by the pituitary/thyroid axis, J. Immunol. 163 (1999) 5883-5890.

[5] C. Arpin, M. Pihlgren, A. Fraichard, D. Aubert, J. Samarut, O. Chassande, J. Marvel, Effects of T3Ralfa1 and T3Ralfa2 thyroid hormone nuclear receptors deletion on $\mathrm{T}$ and $\mathrm{B}$ lymphocyte development, J. Immunol. 164 (2000) 152-160.

[6] G.F. Erf, Immune development in young-adult CRF-hyt mice is affected by congenital and maternal hypothyroidism, Proc. Soc. Exp. Biol. Med. 204 (1993) 40-48.

[7] N. Fabris, E. Moccheggiani, M. Provinciali, Pituitary-thyroid axis and immune system: a reciprocal neuroendocrine-immune interaction, Horm. Res. 43 (1995) 29-38.

[8] K. Dorshkind, N.D. Horseman, The roles of prolactin, growth hormone, insulin-like growth factor-I, and thyroid hormones in lymphocyte development and function: insights from genetic models of hormone and hormone receptor deficiency, Endocr. Rev. 21 (2000) 292-312. 
[9] E. Montecino-Rodriguez, R.G. Clark, A. Johnson, L. Collins, K. Dorshkind, Defective B cell development in Snell dwarf ( $\mathrm{dw} / \mathrm{dw})$ mice can be corrected by thyroxine treatment, J. Immunol. 157 (1996) $3334-3340$.

[10] M.P. Foster, E.R. Jensen, E. Montecino-Rodriguez, H. Leathers, N. Horseman, K. Dorshkind, Humoral and cell-mediated immunity in mice with genetic deficiencies on prolactin, growth hormone, insulinlike growth factor-I, and thyroid hormones, Clin. Immunol. 96 (2000) $140-149$

[11] A. Glynne, J.A. Thomson, Serum immunoglobulin levels in thyroid disease, Clin. Exp. Immunol. 12 (1972) 71-78.

[12] S. Eriksson, Reversible IgA deficiency in hypothyroidism, Postgrad. Med. J. 57 (1981) 714-716.

[13] A.L. Jones, D.J. Webb, Selective IgA deficiency, hypothyroidism and congenital lymphoedema, Scott. Med. J. 41 (1996) 22-23.

[14] B. Alaswad, P. Brosnan, The association of celiac disease, diabetes mellitus type 1 , hypothyroidism, chronic liver disease, and selective IgA deficiency, Clin. Pediatr. (Philadelphia) 39 (2000) 229-231.

[15] J.J.M. De Vijlder, T. Vulsma, Hereditary metabolic disorders causing hypothyroidism, in: L.E. Braverman, R.D. Utiger (Eds.), Werner and Ingbar's: The Thyroid: A Fundamental and Clinical Text, eight ed., Lippincott Williams and Wilkins, Philadelphia, 2000, pp. 733-742.

[16] K.B. Markou, P. Paraskevopoulou, K.S. Karaiskos, M. Makri, N.A. Georgopoulos, G. Iconomou, C. Mengreli, A.G. Vagenakis, Hyperthyrotropinemia during iodide administration in normal children and in children born with neonatal transient hypothyroidism, J. Clin. Endocrinol. Metab. 88 (2003) 617-621.

[17] A.J. Klecha, A.M. Genaro, A.E. Lysionek, R.A. Caro, A.G. Coluccia, G.A. Cremaschi, Experimental evidence pointing to the bidirectional interaction between the immune system and the thyroid system, Int. J. Immunopharmacol. 22 (2000) 491-500.

[18] W. Savino, M. Dardenne, Immune-neuroendocrine interactions, Immunol. Today 16 (1995) 318-322.

[19] A.A. Rooney, M. Fournier, J. Bernier, D.G. Cyr, Neonatal exposure to propylthiouracil induces a shift in lymphoid cell sub-populations in the developing postnatal male rat spleen and thymus, Cell. Immunol. 223 (2003) 91-102.

[20] M.M. Ribeiro-Carvalho, D.A. Farias-de-Oliveira, D.M. Villa-Verde, W. Savino, Triiodothyronine modulates extracellular matrix-mediated interactions between thymocytes and thymic microenvironmental cells, Neuroimmunomodulation 10 (2002-2003) 142-152.

[21] J.R. Klein Jr., Physiological relevance of thyroid stimulating hormone and thyroid stimulating hormone receptor in tissues other than the thyroid, Autoimmunity 36 (2003) 417-421.

[22] J.P. Tan, F.J. Seidler, D.A. Schwinn, S.O. Page, T.A. Skotkin, A critical period for the role of thyroid hormone in development of renal alpha-adrenergic receptors, Pediatr. Res. 42 (1997) $93-102$.

[23] L.D. Metz, F.J. Seidler, E.C. McCook, T.A. Slotkin, Cardiac alphaadrenergic receptor expression is regulated by thyroid hormone during a critical development period, J. Mol. Cell. Cardiol. 28 (1996) 1033-1044.

[24] G. Dan, S.B. Lall, Neuroendocrine modulation of immune system, Ind. J. Pharmacol. 30 (1998) 129-140.

[25] L. Huang, Z.Y. Li, S.Y. Xu, M.Z. Chen, Effects of thyroxine on IgM production and beta-adrenergic receptor on lymphocyte in mice, Shengli Xuebao 42 (1990) 469-475.

[26] J.H. Dussault, Congenital hypothyroidism, in: L.E. Braverman, R.D. Utiger (Eds.), The Thyroid, Lippincott, Philadelphia, 1991, pp. $1222-1228$.

[27] J.A. Hulse, Outcome for congenital hypothyroidism, Arch. Dis. Child. 59 (1984) 23-30.

[28] G. Derken-Lubsen, P.H. Verkerk, Neurological development in early treated congenital hypothyroidism: analysis of literature data, Pediatr. Res. 39 (1996) $561-566$.

[29] S.L. Tillotson, P.W. Fuggle, I. Smith, A.E. Ades, D.B. Grant, Relation between biochemical severity and intelligence in early treated congenital hypothyroidism: a threshold effect, BMJ 309 (1994) $440-445$.

[30] J.A. Germak, T.P. Foley Jr., Longitudinal assessment of Lthyroxine therapy for congenital hypothyroidism, J. Pediatr. 117 (1990) 211-219.

[31] M. Wasniewska, F. De Luca, A. Cassio, N. Oggiaro, P. Gianino, M. Delvecchio, R. Aiazzi, V. Stoppioni, F. Lombardo, M.F. Messina, M. Valenzise, T. Arrigo, In congenital hypothyroidism bone maturation at birth may be a predictive factor of psychomotor development during the first year of life irrespective of other variables related to treatment, Eur. J. Endocrinol. 149 (2003) 1-6. 